\title{
PENGARUH KREDIBILITAS SUMBER DAN RERANGKA PESAN PADA PERSEPSI RISIKO KONSUMEN
}

\author{
Euis Soliha (zulfa_arkan@yahoo.com) \\ Universitas Stikubank Semarang
}

\begin{abstract}
Marketing communication is defined as an attempt by companies to inform, persuade, and remind consumers both directly and indirectly about the products and brands that are sold (Kotler and Keller, 2009: 510). Marketers need to pay attention to the importance of the sender/source/sender/source/endorser is used in advertising. Sender/source/endorser will convey information, persuade or remind consumers about a product or service. Process with celebrity and expert endorsements influence change consumer attitudes and beliefs may be different (Freiden, 1984 as quoted by Biswas et al, 2006). Soliha and Zulfa (2009) suggests there are differences in risk perception of consumers on advertising by using celebrity endorser and expert endorser. Consumers feel the perception of lower risk with expert endorser than celebrity endorser. This indicates that the presences of the use of expert endorsers are more effective than celebrity endorsers in advertising.
\end{abstract}

Keywords: sender, perception, advertising

\section{PENDAHULUAN}

Pada saat ini persaingan di dunia perguruan tinggi sangat ketat. Apalagi dengan adanya fenomena terus menurunnya jumlah peminat atau calon mahasiswa. Jumlah peminat dan jumlah mahasiswa yang diterima di perguruan tinggi swasta dari tahun ke tahun cenderung menurun. Hal yang serupa juga dialami perguruan tinggi negeri. Namun bedanya, meskipun jumlah pendaftar menurun, jumlah mahasiswa baru yang diterima perguruan tinggi negeri terus bertambah. Saat ini 30-40 persen dari 2.679 perguruan tinggi swasta di Indonesia terancam ditutup. Selain akibat pertumbuhan jumlah perguruan tinggi swasta tidak terkendali, penyebab lain karena perguruan tinggi negeri kini cenderung membuka jalur penerimaan mahasiswa secara khusus dan melebihi kuota (Kompas, 14 Oktober 2006).

Berdasarkan data Dikti Juni 2004 jumlah perguruan tinggi negeri di Indonesia sebanyak 82, sedangkan jumlah perguruan tinggi swasta yang tersebar pada 12 Kopertis di Indonesia mencapai hampir 2.700. Di Kopertis Wilayah VI Jawa Tengah jumlah perguruan tinggi swasta sebanyak 175 yang tersebar di berbagai kota di Jawa Tengah. Untuk kota Semarang jumlah perguruan tinggi swasta sebanyak 54 perguruan tinggi. Di Kopertis Wilayah $\vee$ Daerah Istimewa Yogyakarta jumlah perguruan tinggi swasta sebanyak 102. Sementara itu di Jawa Tengah terdapat 5 perguruan tinggi negeri yaitu Undip, Unsoed, UNS, Unnes, Politeknik Negeri Semarang. Sedangkan di Yogyakarta ada 3 perguruan tinggi negeri yaitu UGM, UNY, dan ISI.

Kalau dilihat dari jumlah perguruan tinggi yang ada di Jawa Tengah dan DIY maka persaingan antar perguruan tinggi yang ada khususnya perguruan tinggi swasta begitu ketatnya. Sekarang ini kita bisa melihat begitu maraknya iklan yang disampaikan oleh perguruan tinggi untuk mempengaruhi konsumen.

Akreditasi merupakan salah satu faktor yang harus dipertimbangkan dalam memilih perguruan tinggi. Badan Akreditasi Nasional (BAN-PT) Depdiknas menargetkan semua program studi (prodi) perguruan tinggi di Indonesia terakreditasi sebelum 2012. Menurut Dirjen Dikti Fasli Jalal seperti dikutip Jawa Pos, 5 Januari 2010 bahwa jika tidak memenu hi persyaratan itu, maka prodi perguruan tinggi tersebut tidak boleh mengeluarkan ijazah. Hal ini sesuai dengan PP 19/2005 tentang Standardisasi Nasional Pendidikan (SNP) yang 
mensyaratkan semua prodi perguruan tinggi harus mendapatkan status akreditasi. Jumlah prodi di seluruh Indonesia saat ini sebanyak 15.000 prodi. Prodi yang belum terakreditasi mencapai 7.500 prodi.

Seperti layaknya di perusahaan, banyak perguruan tinggi mempunyai tim pemasaran khusus. Berbagai macam kegiatan promosi dilakukan baik perguruan tinggi swasta maupun pergurvan tinggi negeri. Salah satu alat promosi adalah periklanan. Periklanan adalah segala bentuk penyajian dan promosi ide, barang atau jasa secara non-personal oleh suatu sponsor tertentu (Kotler dan Keller, 2009: 512). Dengan demikian iklan dimaksudkan untuk menginformasikan, membujuk, atau mengingatkan. Untuk dapat mencapai tujuan tersebut, maka iklan harus dikemas dengan baik agar konsumen memberikan respon seperti yang kita harapkan.

Kotler dan Keller (2009: 512 ) menyebutkan terdapat delapan macam bauran komunikasi pemasaran yaitu: periklanan, promosi penjualan, events dan experiences, hubungan masyarakat dan publisitas, pemasaran langsung, pemasaran interaktif, word-of-mouth marketing, serta penjualan pribadi.

Komunikasi pemasaran diartikan sebagai usaha yang dilakukan oleh perusahaan untuk menginformasikan, membujuk, dan mengingatkan konsumen baik langsung maupun tidak langsung mengenai produk dan merek yang dijual (Kotler dan Keller, 2009: 510). Untuk berkomunikasi secara efektif, pemasar perlu memahami sembilan unsur-unsur fundamental yang mendasari komunikasi yang efektif yang melibatkan: (1) sender, (2) encoding, (3) message, (4) media, (5) decoding, (6) receiver, (7) response, (8) feed back, dan (9) noise (Kotler dan Keller, 2009: 514-515). Dua pihak yang utama dalam komunikasi adalah sender dan receiver. Dua alat komunikasi yang utama adalah message dan media. Empat fungsi komunikasi yang utama adalah encoding, decoding, response, dan feedback. Unsur paling akhir dalam sistem komunikasi adalah noise. Pemasar perlu memperhatikan pentingnya pengirim/sumber/sender/source/endorser yang digunakan dalam periklanan. Sender/source/Endorser akan menyampaikan informasi, membujuk ataupun mengingatkan konsumen tentang suatu produk atau jasa. Keputusan konsumen untuk memilih perguruan tinggi membutuhkan keterlibatan yang tinggi. Biasanya seorang konsumen akan mencari informasi tentang perguruan tinggi yang akan dipilihnya. Dalam hal periklanan ini, source/sender/endorser sebagai sumber yang memberikan informasi dengan endorsementsnya memegang peran yang sangat penting sehingga pengelola perguruan tinggi harus bisa memilih source/sender/endorser yang tepat dalam iklannya. Keputusan konsumen dalam memilih perguruan tinggi akan berhubungan dengan berbagai macam risiko diantaranya adalah risiko keuangan, risiko kinerja, risiko sosial, dan risiko psikologi. Semakin tinggi harga produk dan produk dengan semakin tinggi keterlibatan konsumen maka akan semakin tinggi persepsi risiko konsumen.

Mc-Guire (1969) dan Mills (1969) seperti dikutip Friedman dan Friedman (1979) menyebutkan beberapa atribut source/sumber yang meyakinkan yang menyebabkan perubahan sikap adalah trustworthiness, expertise, similarity, attractiveness, dan likableness. Penggunaan endorser dalam iklan dengan endorsementnya diharapkan dapat mengurangi persepsi risiko konsumen.

Soliha dan Zulfa (2009) menunjukkan terdapat perbedaan persepsi risiko konsumen pada iklan dengan menggunakan celebrity endorser dan expert endorser. Konsumen merasakan persepsi risiko yang lebih rendah dengan expert endorser daripada celebrity endorser. Hal ini menunjukkan bahwa adanya penggunaan expert endorser yang lebih efektif daripada celebrity endorser pada periklanan. Iklan perguruan tinggi dengan expert endorser memberikan keyakinan kepada konsumen terhadap kualitas perguruan tinggi tersebut sehingga mengurangi persepsi risiko yang ada. Hasil penelitian ini juga sesuai dengan hasil penelitian sebelumnya oleh Biswas et al (2006) yang menunjukkan bahwa terdapat 
perbedaan persepsi risiko yang lebih rendah pada iklan dengan expert endorser daripada celebrity endorser.

Pengaruh message framing/rerangka pesan dapat dipahami dari perspektif yang ditawarkan peneliti dalam proses informasi. Literatur proses informasi fokus pada proses kognitif dimana konsumen menyatukan bermacam tipe informasi. Dalam marketing dan advertising kita sering menghadapi kesulitan situasi dimana pesan diungkapkan dalam positive terms atau negative terms (sebagai contoh, 85 persen tingkat kepuasan atau 15 persen tingkat ketidakpuasan). Riset juga mengindikasikan bahwa pengaruh pesan tidak sama pada semua kondisi dan dapat dimoderasi oleh faktor-faktor lain.

Melihat bahwa ternyata iklan sangat berperan dalam pengambilan keputusan konsumen untuk memilih perguruan tinggi dan juga melihat begitu pentingnya promosi yang harus dilakukan oleh perguruan tinggi swasta khususnya, maka peneliti tertarik untuk melakukan penelitian mengenai periklanan di dunia perguruan tinggi. Penelitian ini mencoba untuk menguji perbedaan persepsi risiko yang dirasakan konsumen pada iklan dengan menggunakan kredibilitas sumber tinggi dan rendah serta rerangka pesan positif dan negatif.

\section{KAJIAN LITERATUR}

Periklanan

Periklanan adalah segala bentuk penyajian dan promosi ide, barang atau jasa secara nonpersonal oleh suatu sponsor tertentu (Kotler dan Keller, 2009: 512 ). Dengan demikian iklan dimaksudkan untuk menginformasikan, membujuk, atau mengingatkan. Untuk dapat mencapai tujuan tersebut, maka iklan harus dikemas dengan baik agar konsumen memberikan respon seperti yang kita harapkan. Periklanan merupakan hal penting yang harus dilakukan oleh perusahaan. Faktor pentingnya adalah bagaimana mengiklankan produk/jasa secara berbeda dan unik. Iklan yang tampil beda dan membawa pesan yang berbeda pula lebih cepat diterima maknanya oleh konsumen, sehingga konsumen lebih cepat dalam menangkap pesan, produk/jasa dan merek yang diiklankan.

Iklan merupakan komunikasi searah dari produsen kepada konsumen. Komunikasi yang efektif melibatkan: (1) sender, (2) encoding, (3) message, (4) media, (5) decoding, (6) receiver, (7) response, (8) feed back, dan (9) noise (Kotler dan Keller, 2009: 514-515). Sender/Source adalah pusat yang mengidentifikasikan sasaran dan mengembangkan tujuan komunikasi. Encoding adalah proses penterjemahan informasi atau tujuan komunikasi menjadi suatu pesan yang akan disampaikan kepada penerima pesan. Message adalah pesan yang akan disampaikan. Media meliputi pemilihan terhadap media yang akan digunakan untuk menyampaikan pesan. Decoding adalah proses pemahaman atau proses penterjemahan kembali pesan yang diterima melalui media tersebut ke dalam tujuan komunikasi dan disimpan dalam memori penerima pesan. Receiver adalah siapa penerima pesan. Response adalah tanggapan dari penerima pesan. Feed back adalah evaluasi terhadap efektifitas komunikasi.

\section{Pendekatan Model Respon Iklan}

Tujuan iklan dapat dibedakan menjadi tiga fungsi utama yaitu cognitive, affective, dan conactive (Lavidge dan Steiner, 1961 seperti dikutip Enis et al, 1995) Model yang dikemukakan merupakan model hirarki pengaruh advertising yang terdiri dari tiga bagian utama. 


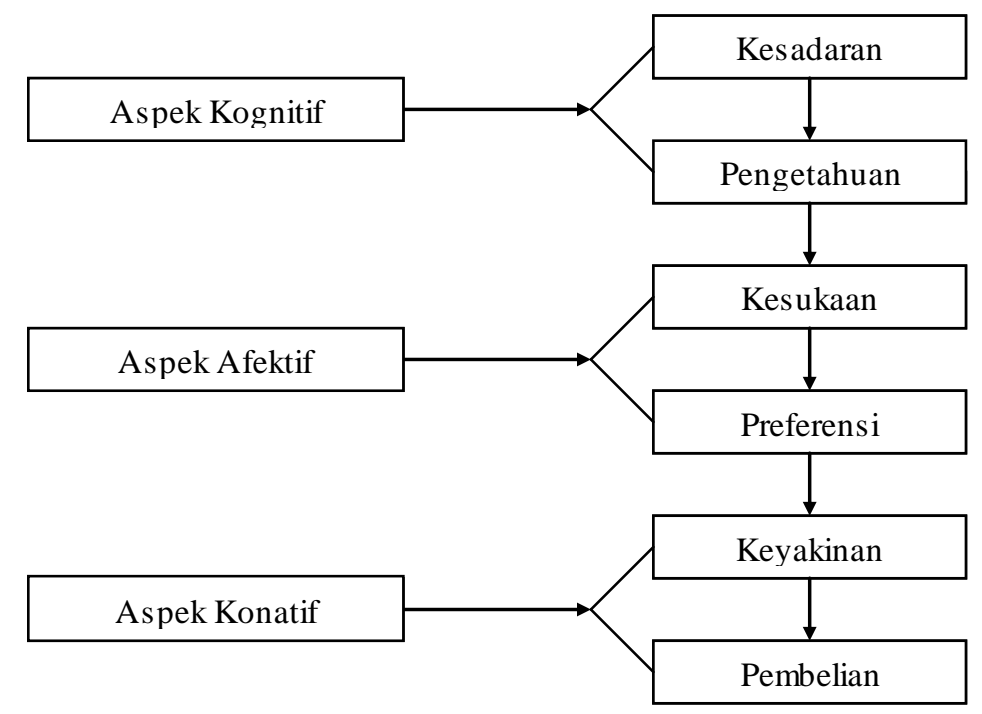

Sumber : Diadaptasi dari Lavidge dan Steiner seperti dikutip Enis et al

Gambar 1

Model Hirarki Efek Lavidge dan Steiner

Fungsi cognitive advertising memberikan informasi dan fakta dengan tujuan membuat konsumen sadar (aware) dan mempunyai pengetahuan (knowledge) tentang merek yang diiklankan. Fungsi affective advertising menciptakan sikap yang lebih menguntungkan. Oleh karena itu fungsi affective advertising ditujukan untuk membujuk konsumen. Fungsi conactive advertising digunakan untuk merangsang keinginan dan menciptakan argumen yang kuat untuk membeli produk yang diiklankan.

\section{Persepsi Risiko Konsumen}

Konsep persepsi risiko berhubungan dengan sejumlah risiko atas pembelian suatu produk atau jasa (Cox dan Rich, 1964; Dowling dan Staelin, 1994). Oleh karena itu semakin tinggi harga produk dan produk dengan semakin tinggi keterlibatan konsumen maka akan semakin tinggi persepsi risiko konsumen.

Jacoby dan Kaplan (1972) dalam Friedman dan Friedman (1979) menyebutkan terdapat lima tipe risiko yang dipersepsikan yaitu: risiko keuangan, risiko kinerja, risiko fisik, risiko psikologi, dan risiko sosial. Performance risk (risiko kinerja) adalah risiko yang dihubungkan dengan ketidakpastian mengenai produk yang kinerjanya tidak sesuai dengan yang diharapkan. Financial risk (risiko keuangan) adalah suatu risiko yang berhubungan dengan semua biaya dan pengeluaran untuk memperoleh produk dan dengan ketidakpastian tentang produk. Risiko tersebut dinilai dengan sejumlah vang (Grewal et al, 1994).

Social risk (risiko sosial) adalah kemungkinan penggunaan produk akan mempengaruhi cara berpikir orang terhadap dirinya. Psychological risk (risiko psikologi) adalah kemungkinan produk tidak sesuai dengan self-image konsumen. Physical risk (risiko fisik) adalah kemungkinan produk akan berbahaya untuk pengguna (Jacoby dan Kaplan, 1972 seperti dikutip Friedman dan Friedman, 1979).

Hubungan Kredibilitas Sumber dan Persepsi Risiko Konsumen

Riset ini didasarkan pada dua teori yaitu: teori source credibility dan teori source attractiveness (Horai dan Fatoullah, 1974 seperti dikutip Biswas et al, 2006). Source Model Theory (SMT) adalah kombinasi dari kedua teori ini. Sesuai dengan SMT, endorsements yang 
efektif biasanya karena adanya source's credibility dan attractiveness (Sternthal dan Craig, 1973 seperti dikutip Biswas et al, 2006).

Kredibilitas sumber/source credibility terdiri dari tiga dimensi yaitu: expertise, trustworthiness, dan physical attractiveness (Ohanian, 1990). Source attractiveness dipandang sebagai tiga aspek yang saling terkait familiarity, similarity, dan liking (McGuire, 1969 seperti dikutip Biswas et al, 2006). Familiarity didefinisikan sebagai pengetahuan akan endorser tertentu karena sering ditampilkan. Similarity adalah kesamaan persepsi di antara pengirim pesan dan penerima pesan. Likability adalah rasa suka kepada endorser karena daya tarik fisik, perilaku, atau kepercayaannya. Credibility theory (Hovland dan Weiss, 1955 seperti dikutip Mittelstaedt et al, 2000) menyatakan bahwa pengirim pesan "credible" jika dia seorang expert, atau orang yang dapat dipercaya.

Seorang celebrity endorser didefinisikan sebagai setiap individu yang dikenal publik dan menggunakan faktor ini sebagai bagian dari produk dengan mempertunjukkannya pada iklan (McCracken, 1989, p.310 seperti dikutip Biswas et al, 2006). Friedman dan Friedman (1979) menyebutkan definisi celebrity endorser adalah individu yang dikenal masyarakat (aktor, atlit, penghibur, dan lain-lain) atas prestasinya di bidang tersebut. Celebrity endorser pada umumnya adalah attractive dan atau likable (Friedman dan Friedman, 1979).

Pengaruh dari celebrity endorsements dijelaskan menggunakan Associative Learning Theory (ALT). Prinsip Associative Learning didasarkan pada konsep tentang memori sebagai sebuah network yang terdiri atas berbagai macam konsep yang dihubungkan dengan associative links (Collins dan Loftus, 1975 seperti dikutip Biswas et al, 2006). Associative Learning Theory merupakan rerangka kerja yang digunakan untuk memahami match-up effects (Till dan Busler, 2000). Source Model Theory (SMT) dan Associative Learning Theory (ALT) diperkirakan berpengaruh pada celebrity endorser.

Seorang expert (ahli) didefinisikan sebagai sumber dengan pernyataan tegas yang valid. Friedman dan Friedman (1979) menyebutkan definisi expert endorser adalah individu atau kelompok yang memiliki pengetahuan yang mendalam terhadap produk yang diiklankannya. Expert endorsement efektif karena sifat komunikasi yang dihasilkan seorang expert endorser lebih disetujui daripada sifat komunikasi yang sama dengan non expert (Tedeschi, 1972 seperti dikutip Biswas et al, 2006). Expert endorser memiliki expertise (Friedman dan Friedman, 1979).

Proses dengan celebrity dan expert endorsements mempengaruhi perubahan sikap dan kepercayaan konsumen mungkin menjadi berbeda (Freiden, 1984 seperti dikutip Biswas et al, 2006). Sesuai dengan Kelman (1961) seperti dikutip Biswas et al (2006) ketika source model dari komunikasi adalah seorang celebrity, perubahan sikap konsumen terjadi melalui proses identifikasi (identification). Identification terjadi ketika individu mencoba membuktikan identitas yang berhubungan dengan celebrity endorser. Ketika sumber/endorser adalah seorang expert (ahli) bagaimanapun pengaruh terjadi melalui proses internalisasi (internalization). Internalization terjadi ketika individu menerima pengaruh yang kongruen/sama dengan sistem nilai atau kepercayaannya. Individu akan terpengaruh dengan seorang expert (ahli) endorser ketika pendapat/pandangannya nampak berguna sebagai solusi masalah yang ada. Secara efektif, expert endorser mungkin mempunyai pengaruh yang lebih besar daripada celebrity endorser. Soliha dan Zulfa (2009) menunjukkan terdapat perbedaan persepsi risiko konsumen pada iklan dengan menggunakan celebrity endorser dan expert endorser. Konsumen merasakan persepsi risiko yang lebih rendah dengan expert endorser daripada celebrity endorser. Hal ini menunjukkan bahwa adanya penggunaan expert endorser yang lebih efektif daripada celebrity endorser pada periklanan. Iklan perguruan tinggi dengan expert endorser memberikan keyakinan kepada konsumen terhadap kualitas perguruan tinggi tersebut sehingga mengurangi persepsi risiko yang ada. Persepsi risiko konsumen dalam penelitian Soliha dan Zulfa (2009) meliputi: persepsi risiko kinerja, persepsi risiko keuangan, persepsi risiko sosial, dan persepsi 
risiko psikologi. Hasil penelitian ini juga sesuai dengan hasil penelitian sebelumnya oleh Biswas et al (2006) yang menunjukkan bahwa terdapat perbedaan persepsi risiko yang lebih rendah pada iklan dengan expert endorser daripada celebrity endorser. Persepsi risiko konsumen dalam penelitian Biswas et al (2006) meliputi: persepsi risiko kinerja dan persepsi risiko keuangan.

Ketika source credibility rendah, attribution theory mengusulkan bahwa konsumen akan mengabaikan argumen dalam pesan (Eagly dan Chaiken, 1975 dalam Grewal et al, 1994). Secara kontras, konsumen lebih cenderung menerima argumen dalam pesan ketika kredibilitas sumber tinggi (Mizerski et al, 1979 dalam Grewal et al, 1994).

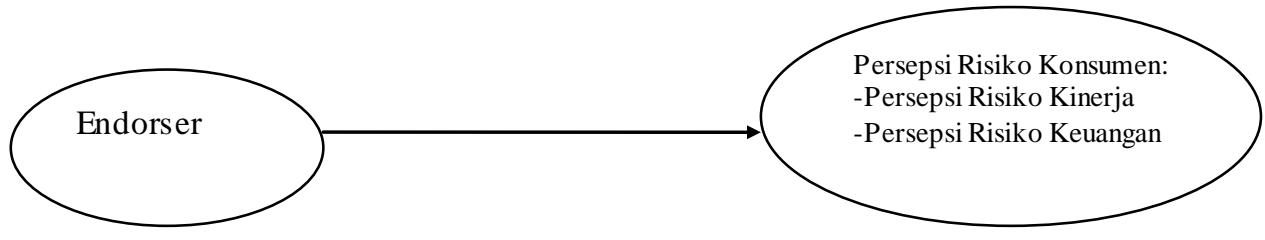

Gambar 2

Model Penelitian Biswas et al (2006)

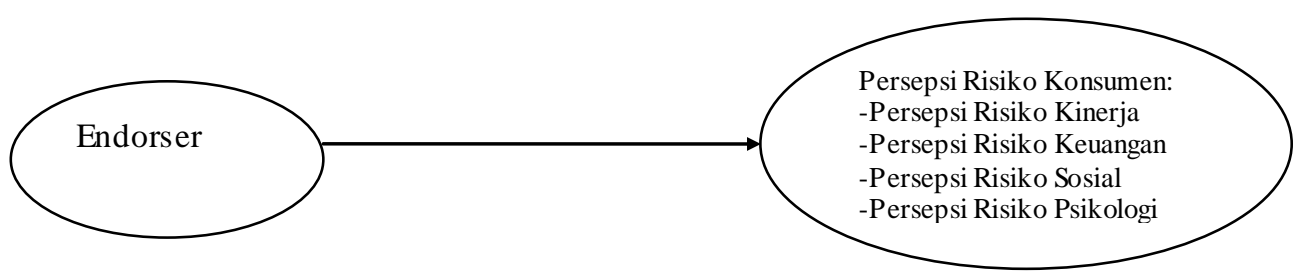

Gambar 3

Model Penelitian Soliha dan Zulfa (2009)

Berdasarkan uraian dan gambar di atas peneliti merumuskan hipotesis pertama sebagai berikut:

H1: Terdapat perbedaan persepsi risiko yang dirasakan konsumen pada iklan dengan menggunakan kredibilitas sumber tinggi dan kredibilitas sumber rendah.

Hubungan Rerangka Pesan dan Persepsi Risiko Konsumen

Pengaruh rerangka pesan dapat dipahami dari perspektif yang ditawarkan peneliti dalam proses informasi. Literatur proses informasi fokus pada proses kognitif dimana konsumen menyatukan bermacam tipe informasi. Dalam marketing dan advertising kita sering menghadapi kesulitan situasi dimana pesan diungkapkan dalam positive terms atau negative terms (sebagai contoh, 85 persen tingkat kepuasan atau 15 persen tingkat ketidakpuasan). Riset juga mengindikasikan bahwa pengaruh pesan tidak sama pada semua kondisi dan dapat dimoderasi oleh faktor-faktor lain.

The Elaboration Model (ELM) mengusulkan bahwa variabel-variabel dapat berpengaruh persuasi dalam sejumlah cara. Mereka dapat sebagai peripheral cues, persuasive argument atau dapat berpengaruh memperluas atau mengarahkan message elaboration (Petty dan Cacioppo, 1986 dalam Buda dan Zhang, 2000). Model ELM menunjukkan cara bagaimana konsumen memproses informasi dalam kondisi keterlibatan tinggi dan keterlibatan rendah. Model ini memberikan rangkaian kesatuan mulai dari pemprosesan informasi yang detil (central) sampai pada pemprosesan informasi yang bersifat tambahan/pelengkap atau bukan hal yang pokok (peripheral). Hal yang bersifat detil dalam istilah Petty dan Cacioppo 
adalah elaboration dan hal-hal yang bersifat tambahan/bukan pokok disebut sebagai nonelaboration. Konsumen yang mempunyai keterlibatan tinggi terhadap suatu produk akan memfokuskan pemrosesan informasi (iklan) pada hal-hal yang inti dan detilnya. Sedangkan konsumen yang mempunyai keterlibatan rendah akan lebih memperhatikan informasi (iklan) pada unsur-unsur yang bukan inti dari iklannya.

Woodside dan Singer (1994) dalam Buda dan Zhang (2000) meneliti variabel lain yang mungkin memoderasi rerangka pesan. Smith (1996) dalam Buda dan Zhang (2000) menemukan pendidikan konsumen lebih dipengaruhi rerangka pesan negatif dan rerangka pesan positif mempunyai pengaruh lebih baik daripada negatif pada pertimbangan pengambilan keputusan pembelian pada transformasional products (produk yang mudah dibawa dan memberikan manfaat pengalaman pada pengguna). Pengaruh harga pada persepsi konsumen pada risiko kinerja lebih besar ketika pesan dalam rerangka negatif dan pengaruh harga pada persepsi konsumen pada risiko keuangan lebih besar ketika pesan dalam rerangka positif (Grewal et al, 1994).

Ketika orang berharap pesan berrerangka negatif, pesan berrerangka positif akan diterima lebih teliti karena pesan berrerangka positif akan menimbulkan konflik dengan harapan individu. Harapan rerangka pesan dalam advertising pada umumnya positif tetapi dalam suatu hal diketahui negatif (misalkan iklan kesehatan).

Rerangka pesan positif didefinisikan sebagai komunikasi yang menekankan keunggulan merek atau keuntungan potensial konsumen dalam suatu situasi. Sedangkan rerangka pesan negatif didefinisikan sebagai komunikasi yang menunjukkan ketidakunggulan merek atau kerugian potensial konsumen dalam suatu situasi (Grewal et al, 1994). Penelitian menggunakan rerangka pesan positif ternyata tidak menemukan pengaruh signifikan harga pada risiko kinerja. Sedangkan pada penelitian menggunakan rerangka pesan negatif, hasil mengusulkan bahwa terdapat hubungan negatif antara harga produk dan persepsi risiko kinerja yang berhubungan dengan pembelian produk (Grewal et al, 1994).

Berdasarkan penelitian Buda dan Zhang (2000) menunjukkan terdapat perbedaan yang signifikan pada rerangka pesan, subyek yang menerima rerangka pesan positif mempunyai tingkat product attitude yang lebih besar secara signifikan daripada subyek yang menerima rerangka pesan negatif.

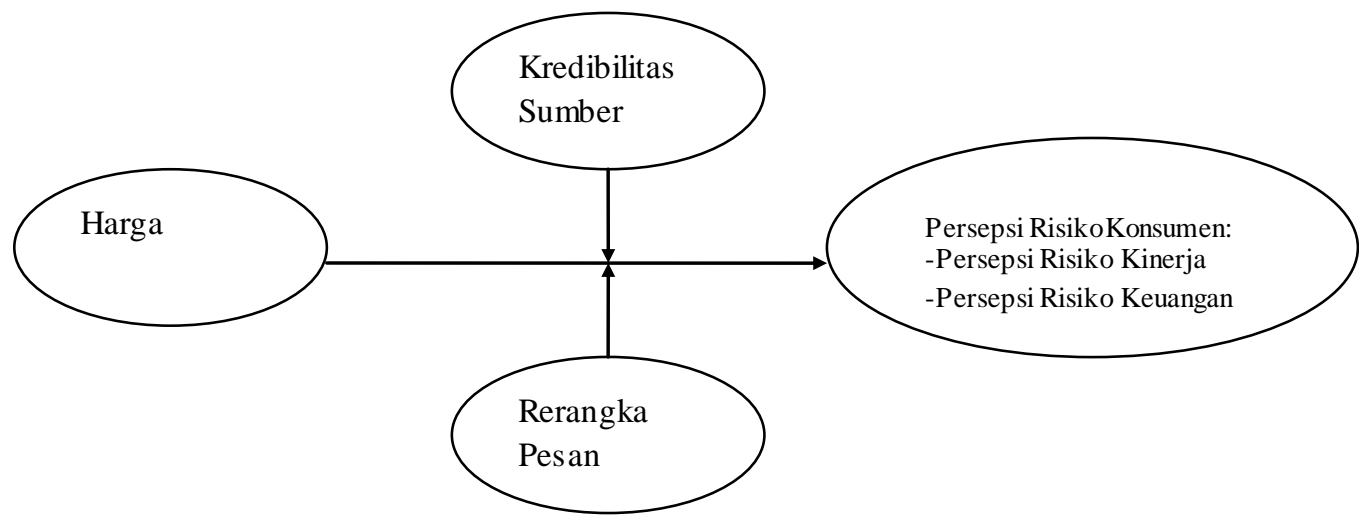

Gambar 4

Model Penelitian Grewal et al (1994) 


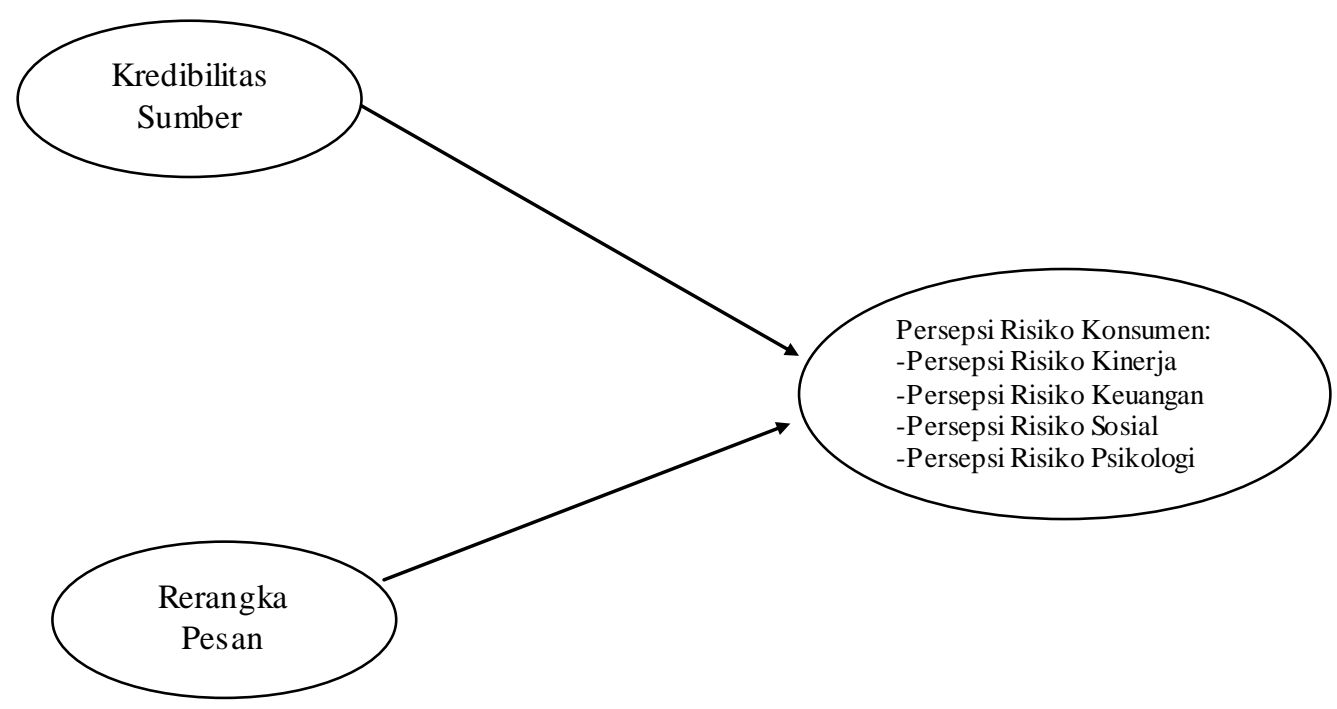

Gambar 5

Model Penelitian Dikembangkan dari Grewal et al (1994), Buda dan Zhang (2000), Biswas et al (2006), Soliha (2007), dan Soliha dan Zulfa (2009)

Berdasarkan uraian dan gambar di atas peneliti merumuskan hipotesis kedua dan ketiga sebagai berikut:

H2: Terdapat perbedaan persepsi risiko yang dirasakan konsumen pada iklan dengan menggunakan rerangka pesan positif dan rerangka pesan negatif.

H3: Terdapat pengaruh yang signifikan pada kredibilitas sumber dan rerangka pesan pada persepsi risiko konsumen.

Kajian Penelitian Sebelumnya

Berikut ini akan dipaparkan berbagai riset mengenai rerangka pesan, kredibilitas sumber dan persepsi risiko konsumen. Pembahasan akan difokuskan pada tahun penelitian, peneliti, variabel yang diteliti, metode penelitian dan alat analisis.

Tabel 1

Kajian Penelitian Sebelumnya

\begin{tabular}{|l|l|l|l|}
\hline No & \multicolumn{1}{|c|}{ Riset } & \multicolumn{1}{|c|}{ Variabel yang Diteliti } & $\begin{array}{l}\text { Metode Penelitian dan } \\
\text { Alat Analisis }\end{array}$ \\
\hline 1. & $\begin{array}{l}\text { Shimp dan Bearden } \\
\text { (1982) }\end{array}$ & $\begin{array}{l}\text { Warranty Quality, Price, } \\
\text { Warrantor Reputation, Financial } \\
\text { Risk, Performance Risk, } \\
\text { Innovative Product }\end{array}$ & $\begin{array}{l}\text { Eksperimen; ANCOVA } \\
\text { dan MANOVA }\end{array}$ \\
\hline 2. & Grewal, et al (1994) & $\begin{array}{l}\text { Messages Framing, Source } \\
\text { Credibility, Price-Perceived Risk }\end{array}$ & $\begin{array}{l}\text { Eksperimen; MANOVA } \\
\text { dan ANOVA }\end{array}$ \\
\hline 3. & Zhang dan Buda (1999) & $\begin{array}{l}\text { Need for Cognition, Source } \\
\text { Credibility, Messages Framing }\end{array}$ & $\begin{array}{l}\text { Eksperimen; MANOVA } \\
\text { dan ANOVA }\end{array}$ \\
\hline 4. & Buda dan Zhang (2000) & $\begin{array}{l}\text { Message Presentation Order, } \\
\text { Source Credibility, Message } \\
\text { Framing, Product Attitude }\end{array}$ & $\begin{array}{l}\text { Eksperimen dan } \\
\text { ANOVA }\end{array}$ \\
\hline 5. & Biswas, et al (2006) & $\begin{array}{l}\text { Tipe Endorser, Perceived } \\
\text { Performance Risk, Perceived } \\
\text { Financial Risk, Consumer }\end{array}$ & $\begin{array}{l}\text { Eksperimen dan } \\
\text { ANOVA }\end{array}$ \\
\hline
\end{tabular}




\begin{tabular}{|l|l|l|l|}
\hline & & Product Knowledge & \\
\hline 6. & Soliha (2007) & $\begin{array}{l}\text { Tipe Endorser, Perceived } \\
\text { Performance Risk. Perceived } \\
\text { Financial Risk, Perceived Social } \\
\text { Risk, Perceived Psychological } \\
\text { Risk, Consumer Product } \\
\text { Knowledge }\end{array}$ & Eksperimen dan \\
ANOVA & \\
\hline 7. & Soliha dan Zulfa (2009) & $\begin{array}{l}\text { Tipe Endorser, Perceived } \\
\text { Performance Risk. Perceived } \\
\text { Financial Risk, Perceived Social } \\
\text { Risk, Perceived Psychological } \\
\text { Risk, Consumer Product } \\
\text { Knowledge }\end{array}$ & ANOVA \\
\hline
\end{tabular}

Pada penelitian ini model penelitian yang peneliti gunakan berdasarkan pada rerangka penelitian pengaruh antara perbedaan kredibilitas sumber dan perbedaan rerangka pesan pada persepsi risiko konsumen yang dikembangkan dari penelitian Soliha dan Zulfa (2009), Soliha (2007), Biswas et al (2006), Buda dan Zhang (2000), Zhang dan Buda (1999), Grewal et al (1994), Shimp dan Bearden (1982). Semua penelitian sebelumnya ini menggunakan desain eksperimen. Pemilihan model didasarkan pada belum jelasnya pengaruh rerangka pesan terhadap persepsi risiko yang dirasakan konsumen pada iklan perguruan tinggi. Peneliti memilih iklan perguruan tinggi karena keputusan konsumen untuk memilih perguruan tinggi membutuhkan keterlibatan yang tinggi. Biasanya seorang konsumen akan mencari informasi tentang perguruan tinggi yang akan dipilihnya. Keputusan konsumen dalam memilih perguruan tinggi juga akan berhubungan dengan berbagai macam risiko diantaranya adalah risiko kevangan, risiko kinerja, risiko sosial, dan risiko psikologi. Semakin tinggi harga produk dan produk dengan semakin tinggi keterlibatan konsumen maka akan semakin tinggi persepsi risiko konsumen.

\section{MODEL PENELITIAN}

Model penelitian yang peneliti gunakan dalam penelitian ini sebagai berikut:

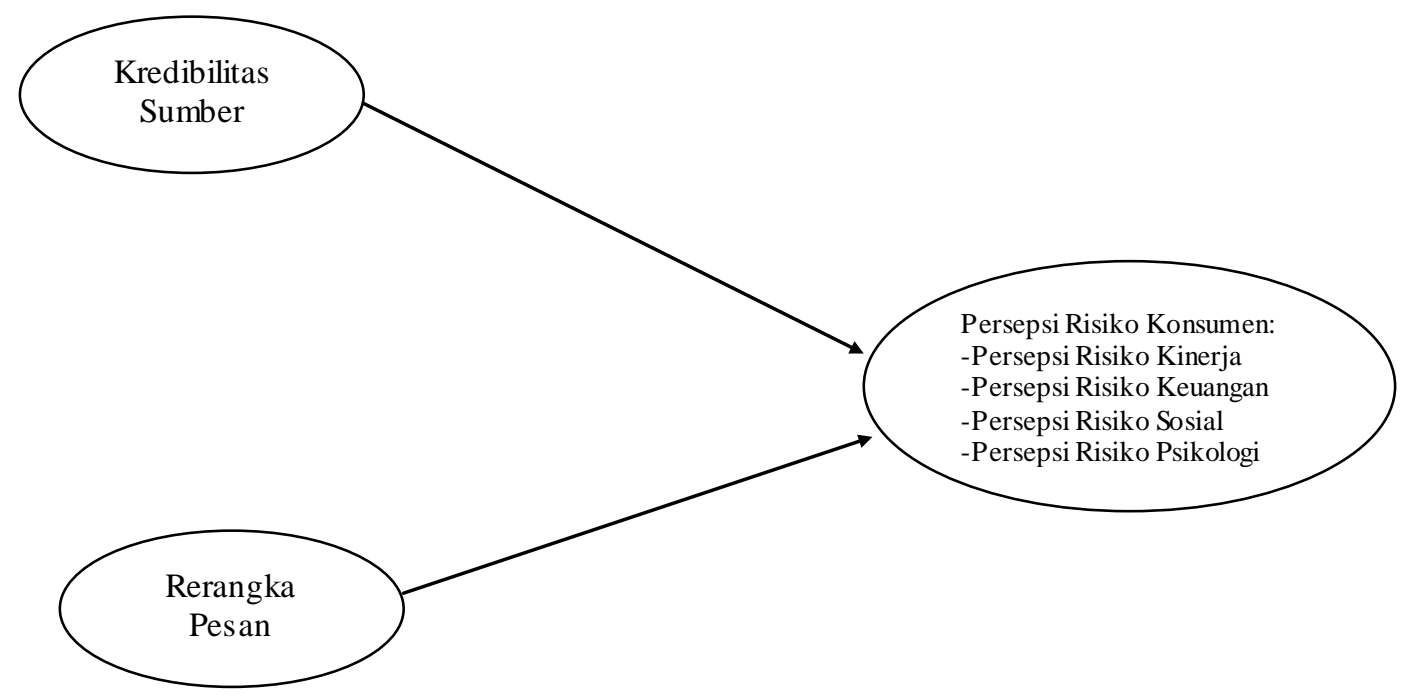

Gambar 6 Model Penelitian 
Berdasarkan model di atas terlihat bahwa persepsi risiko konsumen sebagai variabel independen. Persepsi risiko konsumen ini meliputi: persepsi risiko kinerja, persepsi risiko keuangan, persepsi risiko sosial, dan persepsi risiko psikologi. Sedangkan sebagai variabel dependen adalah kredibilitas sumber yang dimanipulasi dalam kredibilitas sumber tinggi dan kredibilitas sumber rendah serta rerangka pesan yang dimanipulasi dalam rerangka pesan positif dan rerangka pesan negatif. Model yang peneliti ajukan ini mempunyai perbedaan dengan penelitian-penelitian sebelumnya. Pada penelitian ini, persepsi risiko meliputi: persepsi risiko kinerja, persepsi risiko keuangan, persepsi risiko sosial, dan persepsi risiko psikologi. Pada penelitian sebelumnya persepsi risiko hanya meliputi persepsi risiko kinerja dan persepsi risiko keuangan saja.

\section{KESIMPULAN}

Pemasar perlu memperhatikan pentingnya pengirim/sumber/sender/ source/endorser yang digunakan dalam periklanan. Sender/source/endorser akan menyampaikan informasi, membujuk ataupun mengingatkan konsumen tentang suatu produk atau jasa. Soliha dan Zulfa (2009) menunjukkan terdapat perbedaan persepsi risiko konsumen pada iklan dengan menggunakan celebrity endorser dan expert endorser. Konsumen merasakan persepsi risiko yang lebih rendah dengan expert endorser daripada celebrity endorser. Hal ini menunjukkan bahwa adanya penggunaan expert endorser yang lebih efektif daripada celebrity endorser pada periklanan.

Pengaruh rerangka pesan dapat dipahami dari perspektif yang ditawarkan peneliti dalam proses informasi. Riset juga mengindikasikan bahwa pengaruh pesan tidak sama pada semua kondisi dan dapat dimoderasi oleh faktor-faktor lain.

Pada penelitian ini model penelitian yang peneliti gunakan berdasarkan pada rerangka penelitian pengaruh antara perbedaan kredibilitas sumber dan perbedaan rerangka pesan pada persepsi risiko konsumen yang dikembangkan dari penelitian Soliha dan Zulfa (2009), Soliha (2007), Biswas et al (2006), Buda dan Zhang (2000), Zhang dan Buda (1999), Grewal et al (1994), Shimp dan Bearden (1982). Semua penelitian sebelumnya ini menggunakan desain eksperimen. Pemilihan model didasarkan pada belum jelasnya pengaruh message framing terhadap persepsi risiko yang dirasakan konsumen pada iklan perguruan tinggi .

\section{DAFTAR PUSTAKA}

Aaker, D.A; V. Kumar; and G.S. Day (2004), Marketing Research, $8^{\text {th }}$ ed. New York: John Wiley \& Sons, Inc.

Alba, Joseph W. and J. W. Hutchinson (1987), "Dimensions of Consumer Expertise," Journal of Consumer Research, 13 (March), pp. 411-454.

Assael, H (2001), Consumer Behavior and Marketing Action, $7^{\text {th }}$ ed. Singapore: Thomson Learning.

Atkin, Charles and M. Block (1983), "Effectiveness of Celebrity Endorsers," Journal of Advertising Research, 23 (February/March), pp. 57-61.

Biswas, Dipayan; A. Biswas; and N. Das (2006), "The Differential Effects of Celebrity and Expert Endorsements on Consumer Risk Perceptions," Journal of Advertising, 35 (Summer), pp. 17-31.

Buda, Richard and Y. Zhang (2000), "Consumer Product Evaluation: The Interactive Effect of Message Framing, Presentation Order, and Source Credibility," Journal of Product and Brand Management, Vol.9, No.4, pp. 229-242.

Christensen, B, Larry (1988), Experimental Methodology, $4^{\text {th }}$ ed. Boston: Allyn and Bacon, Inc. 
Cox, Donald F and S. J. Rich (1964), "Perceived Risk and Consumer Decision Making," Journal of Marketing Research, 1 (November), pp. 32-39.

Crask, M; R.J.Fox; and R.G.Stout (1995), Marketing Research: Principles and Applications, Englewood Cliffs, NJ: Prentice-Hall.

Dharmmesta, Basu Swastha (1997), Segi-segi Penulisan Karya IImiah, Magister Manajemen, UGM, Yogyakarta.

Dowling, Grahame R. and R. Staelin (1994), "A Model of Perceived Risk and Intended RiskHandling Activity," Journal of Consumer Research, 21 (June), pp. 119-134.

Friedman, Hershey H and L. Friedman (1979), "Endorser Effectiveness by Product Type," Journal of Advertising Research, 19 (October), pp 63-71.

Grewal, Dhruv; J. Gotlieb; and H. Marmorstein (1994), "The Moderating Effects of Message Framing and Source Credibility on the Price-Perceived Risk Relationship," Journal of Consumer Research, 21 (June), pp. 145-153.

Jawa Pos, Senin 4 Januari 2010.

Kompas, Sabtu 14 Oktober 2006, hal. 12.

Kotler, P. and K.L.Keller (2009), Marketing Management, 13 th ed. Upper Saddle River, NJ: Pearson Education, Inc.

Lavidge, Robert J and G. A. Steiner, "A Model for Predictive Measurements of Advertising Effectiveness" in B.M. Enis; K.K. Cox; and M.P. Mokwa, Marketing Classic: A Selection of Influential Articles, 8th ed. London, Allyn and Bacon, pp. 523-527.

Mittelstaedt, John D; P. C. Riesz; and W. J. Burns (2000), "Why are Endorsements Effective? Sorting Among Theories of Product and Endorser Effects," Journal of Current Issues and Research in Advertising, Vol. 22 (Spring), No. 1.

Neuman, W. Lawrence (2003), Social Research Methods: Qualitative and Quantitative Approaches, $5^{\text {th }}$ ed. London: Allyn and Bacon.

Ohanian, Roobina (1990), "Construction and Validation of a Scale to Measure Celebrity Endorsers' Perceived Expertise, Trustworthiness, and Attractiveness," Journal of Advertising, Vol.19, No.3, pp. 39-52.

Park, C.Whan; D. L. Mothersbaugh; and L. Feick (1994), "Consumer Knowledge Assessment," Journal of Consumer Research, 21 (June), pp 71-82.

Shimp, Terence A. and W. O. Bearden (1982), "Warranty and Other Extrinsic Cue Effects on Consumers' Risk Perceptions," Journal of Consumer Research, 9 (June), pp 38-46.

Soliha, Euis (2007), "Perbedaan Persepsi Risiko Konsumen antara Iklan dengan Menggunakan Celebrity Endorser dan Expert Endorser," Thesis Strata 2 Magister Sains (MSi), Fakultas Ekonomika dan Bisnis, Universitas Gadjah Mada, Yogyakarta (tidak dipublikasikan).

Soliha, Euis and N. Zulfa (2009), "The Difference in Consumer Risk Perception between Celebrity Endorser and Expert Endorser in College Advertisements," Journal of Indonesian Economy \& Business, Vol.24, No.1, January, pp. 100-114.

Stone, Robert N. and K. Gronhaug (1993), "Perceived Risk: Further Considerations for the Marketing Discipline," European Journal of Marketing, Vol.27, No.3, pp 39-50.

Suara Merdeka, 28 Februari 2009.

Sutisna (2003), Perilaku Konsumen dan Komunikasi Pemasaran, PT Remaja Rosdakarya Offset, Bandung.

Till, Brian D. and M. Busler (2000), "The Match-Up Hypothesis: Physical Attractiveness, Expertise, and the Role of Fit on Brand Attitude, Purchase Intent and Brand Beliefs," Journal of Advertising, Vol.29, No.3, pp. 1-13.

Zhang, Yong and R. Buda (1999), "Moderating Effects of Need for Cognition on Responses to Positively versus Negatively Framed Advertising Messages," Journal of Advertising, Vol. XXVIII, No.2 Summer 